\title{
Antihypertensive Effect of Spironolactone (SC-9420) on Experimental Renal Hypertension
}

\author{
By \\ Soitsu Fukuchi, Ryuji Shioji and Suezaburo Abe \\ From the Department of Internal Medicine, Tohoku University \\ School of Medicine, Sendai; Director: Prof. Dr. T. Torikai
}

(Received for publication, October 21, 1961)

\section{INTRODUCTION}

Over many years numerous reports have suggested that hypertrophy and hyperplasia in adrenal cortex, with an increase in sudanophilic lipids, occur more frequently in clinical renal and essential hypertensions than in normotension ${ }^{1,2}$. The blood pressure of a majority of patients with malignant hypertension could be significantly lowered by removing the enlarged adrenals. ${ }^{3)}$

On the other hand, many investigators agreed that total adrenalectomy in dogs and rats with experimental renal hypertension resulted in a significant decrease of the hypertension. $4,5,6,7)$

It has still not been clarified that the antihypertensive effect, caused by complete adrenalectomy, is due to a nonspecific effect of the cortical insufficiency or due in part to the disappearance of a pathogenic role of adrenal cortex in experimental renal hypertension.

Sturtevant ${ }^{8,9,10,11)}$ described that a synthetic steroid, SC-6584 reduced the blood pressure of rats with metacorticoid, metarenal and adrenal-regeneration types of hypertension. Spironolactone, SC-9420, 3 (3-keto-7 $\alpha$-acetylthio-17 $\beta$ hydroxy-4-androsten-17 $\gamma$-yl)-propionic acid- $\gamma$-lactone, a new compound synthesized by Cella and Kagawa, blocks the effects of desoxycorticosterone acetate (DCA) on serum and urinary electrolytes in rats. It is reported that its oral potency as a DCA-blocker is about 5 times as much as that of SC-8109.

The purpose of the present study has been to know the effect of SC-9420 on blood pressure and electrolyte and water metabolism in experimental renal hypertensive rabbits.

\section{EXPERIMENTAL MATERIALS AND METHODS}

Nine male rabbits, averaging $3.0 \mathrm{~kg}$. in weight, were placed individually in metabolic cages and divided randomly into 4 groups. Hypertension was produced

福地 総逸, 塩路 隆治, 阿部 末三郎 
by the application of a figure-of-eight ligature to one kidney with removal of the contralateral kidney. Thereafter, the rabbits were provided with the standard diet, in which $\mathrm{NaCl}$ at the quantity of $10 \mathrm{mEq} . / \mathrm{kg}$. was supplemented, for about 50 days. Roughly two-third of the rabbits became hypertensive and the systolic blood pressure level rose to more than $100 \mathrm{~mm} \mathrm{Hg}$. The five hypertensive rabbits were divided into two groups. One group of 2 hypertensive rabbits was intramuscularly administered on the daily dose of $200 \mathrm{mg}$. of SC-9420, suspended in $5 \mathrm{ml}$. of sesame oil, for 6 days. The second group of 3 experimental renal hypertensive rabbits was given a similar dose of this compound orally for 6 days. The third group of two rabbits with normal arterial pressure received only the solvent (sesame oil) intramuscularly. The last group of two normotensive rabbits received $200 \mathrm{mg}$. of SC-9420 orally for the same period. All these groups were given $10 \mathrm{mEq}$. of sodium chloride, $25 \mathrm{mEq}$. of potassium and $60 \mathrm{ml}$. of water per kilogram of body weight, daily throughout the experimental period.

Urine was collected by means of an indwelling catheter and the volume and the sodium and potassium concentrations were measured on each day. Measurements of serum and urinary sodium and potassium were made by flame photometry. Body weight and blood pressure were recorded under the standard conditions at the beginning of each metabolic day. Blood pressure was indirectly estimated by the method of Watson. ${ }^{12}$ )

SC-9420 was kindly provided by Dr. V. A. Drill, Director of Biological Research, G.D. Searle \& Co.

\section{RESULTS}

The effects of SC-9420 are shown in Table I on renal hypertensive rabbits and in Table II on normotensive rabbits. The body weight showed little changes in all groups. The blood pressure was reduced to approximately normal levels in the hypertensive groups treated with spironolactone, but did not change in the normotensive groups. The reduced blood pressure began to rise again 3 or 4 days after the cessation of spironolactone therapy and returned to more than $100 \mathrm{~mm}$ $\mathrm{Hg}$. on the 5th day (Fig. 1). In the hypertensive groups, there were increases in urinary sodium and urinary volume, mostly accompanied by a slight decrease in urinary potassium. A significant increase of serum potassium and a minor decrease of serum sodium were observed during spironolactone therapy, but no changes of serum electrolytes was observed in normotensive groups. There was no decrease of urinary potassium corresponding to this increase of serum potassium. It was observed that in all hypertensive groups the elevation of urinary volume and sodium excretion occurred on the second to fourth day of spironolactone administration and this effect continued for about 3 days after the withdrawal of spironolactone (Figs. 2 and 3). In the hypertensive rabbits the electrolyte effect of spironolactone administered orally was similar to the intramuscular injection. 
TABLE I. Hypotensive Effect of Spironolactone on Renal Hypertensive Rabbits.

\begin{tabular}{|c|c|c|c|c|c|c|c|c|}
\hline \multirow{2}{*}{$\begin{array}{c}\text { Number } \\
\text { of } \\
\text { Rabbits }\end{array}$} & \multirow{2}{*}{ Treatment } & \multirow{2}{*}{$\begin{array}{c}\text { Body } \\
\text { Weight } \\
\text { Kg. }\end{array}$} & \multirow{2}{*}{$\begin{array}{l}\text { Blood } \\
\text { Pressure } \\
\text { mm. Hg. }\end{array}$} & \multicolumn{2}{|c|}{ Serum } & \multicolumn{3}{|c|}{ Urinary } \\
\hline & & & & $\begin{array}{l}\text { Sodium } \\
\mathrm{mEq} . / \mathrm{L} .\end{array}$ & $\begin{array}{c}\text { Potassium } \\
\mathbf{m E q} \cdot / \mathbf{L}\end{array}$ & $\begin{array}{c}\text { Volume } \\
\text { ml./d. }\end{array}$ & $\begin{array}{l}\text { Sodium } \\
\mathrm{mEq} / \mathrm{d} .\end{array}$ & $\begin{array}{l}\text { Potassium } \\
\mathrm{mEq} / \mathrm{d}\end{array}$ \\
\hline 1 & $\begin{array}{l}\text { SC-9420 } \\
200 \mathrm{mg} . \\
\text { per day } \\
\text { i. } \mathrm{m} .\end{array}$ & $\begin{array}{l}2.7 \\
2.7 \\
2.7 \\
2.9 \\
2.8\end{array}$ & $\begin{array}{r}109 \\
105 \\
95 \\
68 \\
\\
70 \\
62 \\
62 \\
100\end{array}$ & $\begin{array}{c}139 \\
136 \\
134.5 \\
136\end{array}$ & $\begin{array}{l}4.3 \\
4.5 \\
4.8 \\
4.6\end{array}$ & $\begin{array}{l}170 \\
150 \\
130 \\
180 \\
150 \\
175 \\
190 \\
210 \\
220 \\
210 \\
230 \\
140 \\
225 \\
210 \\
150 \\
170\end{array}$ & $\begin{array}{l}23 \\
23 \\
17 \\
20 \\
14 \\
22 \\
27 \\
26 \\
28 \\
19 \\
25 \\
25 \\
32 \\
27 \\
20 \\
23\end{array}$ & $\begin{array}{l}21 \\
21 \\
20 \\
20 \\
17 \\
27 \\
17 \\
17 \\
18 \\
21 \\
20 \\
22 \\
24 \\
20 \\
13 \\
18\end{array}$ \\
\hline 2 & $\begin{array}{l}\text { SC-9420 } \\
200 \mathrm{mg} . \\
\text { per day } \\
\text { i. } \mathrm{m} \text {. }\end{array}$ & $\begin{array}{l}3.25 \\
3.4 \\
3.5\end{array}$ & $\begin{array}{r}118 \\
\\
116 \\
110 \\
75 \\
65 \\
68 \\
65 \\
\\
70 \\
\\
110\end{array}$ & $\begin{array}{l}143 \\
141.5 \\
139 \\
\quad \\
140\end{array}$ & $\begin{array}{l}4.2 \\
4.9 \\
5.0\end{array}$ & $\begin{array}{l}140 \\
130 \\
130 \\
115 \\
110 \\
160 \\
140 \\
125 \\
140 \\
225 \\
260 \\
265 \\
235 \\
210 \\
170 \\
200\end{array}$ & $\begin{array}{l}19 \\
17 \\
20 \\
18 \\
15 \\
16 \\
20 \\
25 \\
27 \\
30 \\
32 \\
32 \\
34 \\
32 \\
18 \\
20\end{array}$ & $\begin{array}{l}12 \\
13 \\
15 \\
12 \\
14 \\
19 \\
14 \\
11 \\
15 \\
17 \\
16 \\
24 \\
18 \\
18 \\
16 \\
18\end{array}$ \\
\hline 3 & $\begin{array}{l}\text { SC-9420 } \\
200 \mathrm{mg} \text {. } \\
\text { per day } \\
\text { i. m. }\end{array}$ & $\begin{array}{l}3.2 \\
3.0 \\
3.1\end{array}$ & $\begin{array}{r}110 \\
110 \\
114 \\
105 \\
85 \\
70 \\
67 \\
58 \\
68 \\
88 \\
112\end{array}$ & $\begin{array}{l}140 \\
141\end{array}$ & $\begin{array}{l}3.6 \\
3.5\end{array}$ & $\begin{array}{l}190 \\
200 \\
210 \\
200 \\
160 \\
190 \\
200 \\
230 \\
220 \\
220 \\
240 \\
230 \\
190 \\
170\end{array}$ & $\begin{array}{l}25 \\
30 \\
23 \\
34 \\
27 \\
25 \\
29 \\
35 \\
38 \\
36 \\
35 \\
33 \\
29 \\
40\end{array}$ & $\begin{array}{l}22 \\
21 \\
22 \\
23 \\
19 \\
22 \\
18 \\
23 \\
20 \\
25 \\
22 \\
20 \\
20 \\
30\end{array}$ \\
\hline
\end{tabular}




\begin{tabular}{|c|c|c|c|c|c|c|c|c|}
\hline 4 & $\begin{array}{l}\mathrm{SC}-9420 \\
200 \mathrm{mg} . \\
\text { per day } \\
\text { orally }\end{array}$ & $\begin{array}{l}3.1 \\
3.1 \\
3.1 \\
3.1 \\
3.2 \\
3.1\end{array}$ & $\begin{array}{r}108 \\
106 \\
\\
100 \\
84 \\
72 \\
66 \\
66 \\
56 \\
56 \\
54 \\
60 \\
70 \\
104\end{array}$ & $\begin{array}{l}148 \\
147 \\
143 \\
143 \\
146\end{array}$ & $\begin{array}{l}4.9 \\
5.0 \\
4.5\end{array}$ & $\begin{array}{l}240 \\
210 \\
210 \\
250 \\
180 \\
250 \\
230 \\
250 \\
300 \\
320 \\
330 \\
280 \\
260 \\
230 \\
220 \\
240\end{array}$ & $\begin{array}{l}29 \\
31 \\
26 \\
27 \\
30 \\
25 \\
33 \\
35 \\
41 \\
38 \\
42 \\
44 \\
35 \\
40 \\
34 \\
39\end{array}$ & $\begin{array}{l}21 \\
19 \\
22 \\
23 \\
13 \\
28 \\
22 \\
21 \\
19 \\
20 \\
19 \\
20 \\
20 \\
21 \\
21 \\
23\end{array}$ \\
\hline 5 & $\begin{array}{l}\text { SC-9420 } \\
200 \mathrm{mg} . \\
\text { per day } \\
\text { orally }\end{array}$ & $\begin{array}{l}2.9 \\
2.9 \\
\\
2.8 \\
\\
2.9 \\
2.9 \\
2.8 \\
2.8 \\
2.9 \\
2.9 \\
2.9 \\
2.9 \\
2.9 \\
\\
2.9\end{array}$ & $\begin{array}{r}100 \\
100 \\
105 \\
110 \\
98 \\
76 \\
78 \\
74 \\
68 \\
68 \\
68 \\
78 \\
\\
102\end{array}$ & $\begin{array}{l}143 \\
141 \\
142 \\
145\end{array}$ & $\begin{array}{l}4.4 \\
4.6 \\
4.5 \\
4.3\end{array}$ & $\begin{array}{l}250 \\
250 \\
210 \\
260 \\
230 \\
260 \\
250 \\
290 \\
300 \\
300 \\
320 \\
300 \\
280 \\
230 \\
210 \\
200\end{array}$ & $\begin{array}{l}30 \\
31 \\
26 \\
30 \\
26 \\
33 \\
30 \\
35 \\
39 \\
35 \\
34 \\
44 \\
35 \\
28 \\
26 \\
25\end{array}$ & $\begin{array}{l}23 \\
31 \\
26 \\
31 \\
26 \\
23 \\
26 \\
19 \\
23 \\
19 \\
21 \\
22 \\
20 \\
20 \\
20 \\
22\end{array}$ \\
\hline
\end{tabular}

The antihypertensive effect of spironolactone in rabbits with experimental renal hypertension appeared immediately after start of administration, and the blood pressure stayed at normal levels (less than $100 \mathrm{~mm} \mathrm{Hg}$.) during the period of the administration. This changes of blood pressure were not coincident with those of the urinary sodium.

\section{DISCUSSION}

The possibility of a pathogenetic change of adrenal cortical function in experimental renal hypertension has been suggested by alterations in sodium and water metabolisms in renal hypertensive dogs and rats. In the rat with experimental renal hypertension, the adrenal cortex is enlarged and histological studies reveal hypertrophy of the zona glomerulosa ${ }^{13)}$ and hyaline droplet inclusions in the cells of the zona fasciculata. ${ }^{14}$ Investigators agree that complete removal of the adrenal cortex in dogs and rats with acute and chronic experimental renal hypertensions results in a significant decrease of the hypertension. ${ }^{4,5,6,7)}$ Laragh et $a l .{ }^{15)}$ found that aldosterone plays an important role in the syndrome of malig- 
TABLE II. Effect of Spironolactone or Sesame Oil Administration on Normotenisve Rabbits.

\begin{tabular}{|c|c|c|c|c|c|c|c|c|}
\hline \multirow{2}{*}{$\begin{array}{c}\text { Number } \\
\text { of } \\
\text { Rabbits }\end{array}$} & \multirow[t]{2}{*}{ Treatment } & \multirow{2}{*}{$\mid \begin{array}{c}\text { Body } \\
\text { Weight } \\
\text { Kg. }\end{array}$} & \multirow{2}{*}{$\begin{array}{l}\text { Blood } \\
\text { Pressure } \\
\mathrm{mm} . \mathrm{Hg}\end{array}$} & \multicolumn{2}{|c|}{ Serum } & \multicolumn{3}{|c|}{ Urinary } \\
\hline & & & & $\begin{array}{l}\text { Sodium } \\
\mathrm{mEq} \cdot / \mathrm{L} .\end{array}$ & $\begin{array}{l}\text { Potassium } \\
\mathrm{mEq} \cdot / \mathrm{L}\end{array}$ & $\begin{array}{l}\text { Volume } \\
\text { ml./d. }\end{array}$ & $\begin{array}{l}\text { Sodium } \\
\mathrm{mEq} \cdot / \mathrm{d} .\end{array}$ & $\begin{array}{l}\text { Potassium } \\
\mathrm{mEq} . / \mathrm{d} .\end{array}$ \\
\hline 1 & $\begin{array}{l}\text { SC-9420 } \\
200 \mathrm{mg} . \\
\text { per day } \\
\text { orally }\end{array}$ & $\begin{array}{l}3.0 \\
3.0 \\
3.1 \\
3.1 \\
3.0 \\
3.1 \\
3.1\end{array}$ & $\begin{array}{l}59 \\
59 \\
56 \\
58\end{array}$ & $\begin{array}{l}130 \\
137 \\
138\end{array}$ & $\begin{array}{l}3.4 \\
3.0 \\
3.6\end{array}$ & $\begin{array}{l}150 \\
210 \\
205 \\
150 \\
200 \\
150 \\
155 \\
150 \\
170 \\
140 \\
205 \\
200 \\
200\end{array}$ & $\begin{array}{l}29 \\
29 \\
22 \\
23 \\
27 \\
24 \\
20 \\
21 \\
22 \\
15 \\
27 \\
32 \\
31\end{array}$ & $\begin{array}{l}13 \\
20 \\
15 \\
13 \\
15 \\
16 \\
12 \\
14 \\
15 \\
12 \\
21 \\
16 \\
16\end{array}$ \\
\hline 2 & $\begin{array}{l}\mathrm{SC}-9420 \\
200 \mathrm{mg} \text {. } \\
\text { per day } \\
\text { orally }\end{array}$ & $\begin{array}{l}3.5 \\
3.5 \\
3.2 \\
3.4 \\
3.3 \\
3.2 \\
\\
3.1 \\
3.1 \\
3.2\end{array}$ & $\begin{array}{l}72 \\
68 \\
70 \\
70 \\
66 \\
68 \\
62 \\
70 \\
60 \\
58 \\
56 \\
58 \\
60 \\
62\end{array}$ & $\begin{array}{l}147 \\
148 \\
149 \\
149\end{array}$ & $\begin{array}{l}4.5 \\
4.2\end{array}$ & $\begin{array}{l}230 \\
210 \\
260 \\
200 \\
180 \\
180 \\
170 \\
200 \\
220 \\
220 \\
230 \\
200 \\
200 \\
180 \\
190\end{array}$ & $\begin{array}{l}28 \\
29 \\
34 \\
30 \\
30 \\
30 \\
33 \\
27 \\
26 \\
31 \\
33 \\
31 \\
29 \\
31 \\
29\end{array}$ & $\begin{array}{l}18 \\
18 \\
15 \\
17 \\
16 \\
16 \\
14 \\
14 \\
15 \\
18 \\
15 \\
12 \\
15 \\
16 \\
14\end{array}$ \\
\hline 3 & $\begin{array}{l}\text { Sesame } \\
\text { Oil } \\
5 \mathrm{cc} \\
\text { i. } \mathrm{m} \text {. }\end{array}$ & $\begin{array}{l}2.9 \\
3.0\end{array}$ & $\begin{array}{l}63 \\
65\end{array}$ & $\begin{array}{r}138 \\
138 \\
137 \\
138 \\
138\end{array}$ & $\begin{array}{l}3.5 \\
3.5 \\
3.5\end{array}$ & $\begin{array}{l}170 \\
140 \\
180 \\
190 \\
150 \\
160 \\
180 \\
170 \\
190 \\
140 \\
160\end{array}$ & $\begin{array}{l}27 \\
23 \\
25 \\
29 \\
25 \\
26 \\
27 \\
23 \\
29 \\
25 \\
25\end{array}$ & $\begin{array}{l}18 \\
21 \\
16 \\
18 \\
15 \\
20 \\
23 \\
16 \\
22 \\
18 \\
22\end{array}$ \\
\hline
\end{tabular}




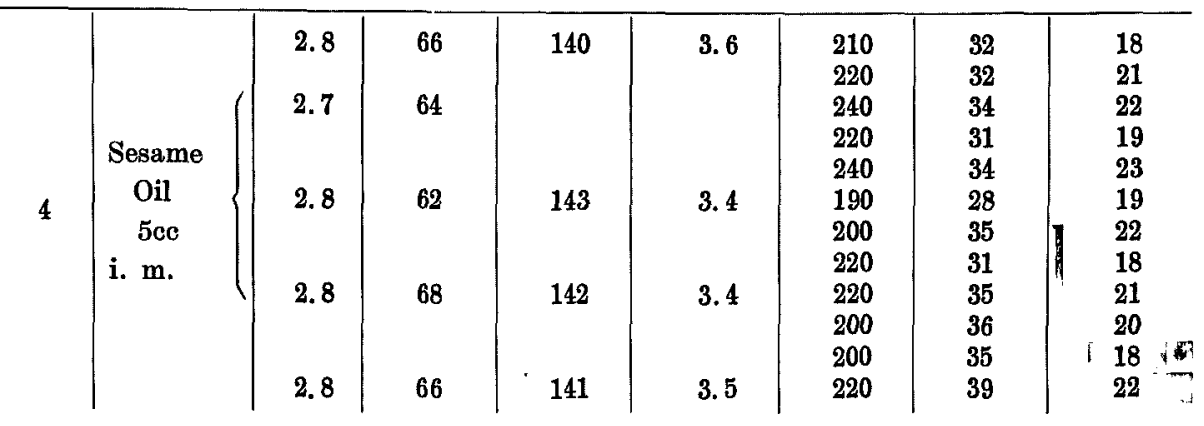

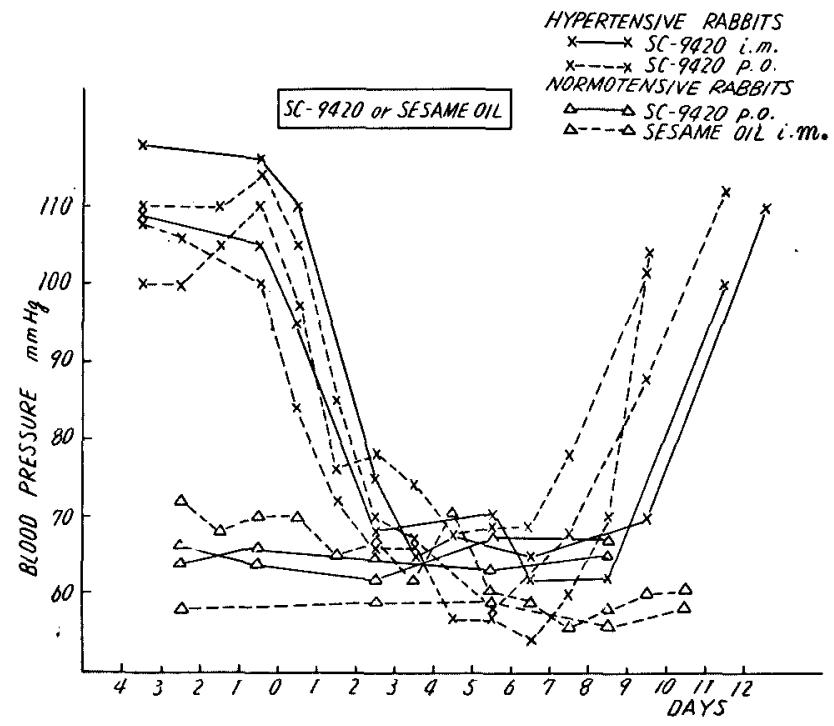

Fig. 1. Effect of SC-9420 upon blood pressure in renal hypertensive and normotensive rabbits.

nant hypertension, by estimating aldosterone secretion.

Sturtevant ${ }^{11)}$ showed that chronic administration of the hypotensive steroid, SC-6584, to rats actively treated with DCA-sodium chloride, tended to interfere with the pressor action of DCA, although these data were not definite. Hollander ${ }^{15)}$ reported that spironolactone had hypotensive effects in a half of hypertensive patients, but had not in normotensive subjects. From the present study, a large amount of spironolactone may be useful as antihypertensive agents to renal hypertension.

The present study showed its hypotensive effect for experimental renal hypertensive rabbits. At the same time, it was observed that urinary sodium and volume increased. Spironolactone has been reported to exhibit its charac- 


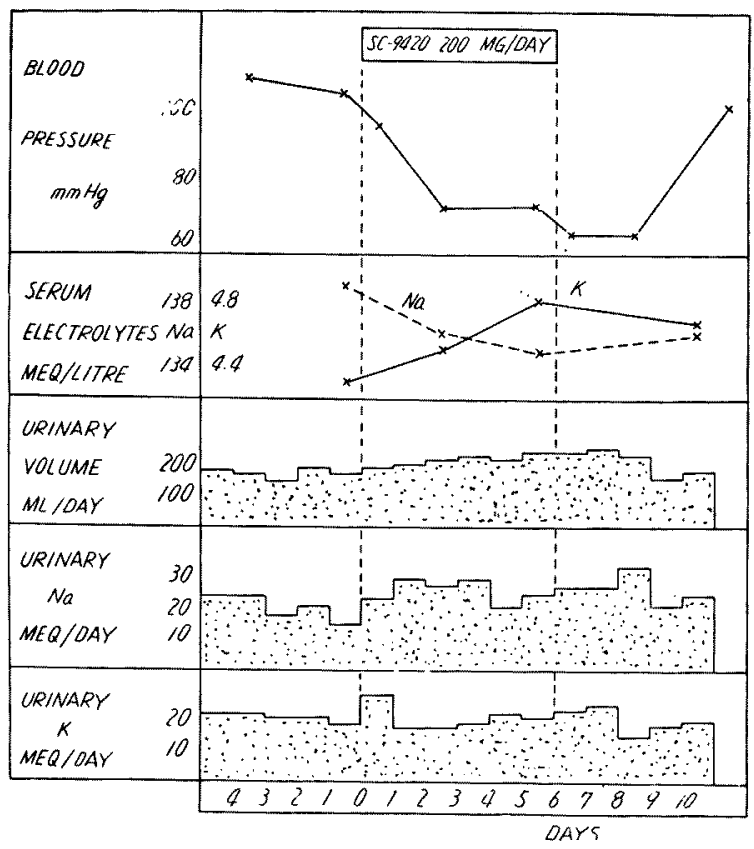

Fig. 2. Effect of SC-9420 upon blood pressure, serum sodium and potassium and urinary volume, sodium and potassium in renal hypertensive rabbit.

Fig. 3. Effect of SC-9420, in oral dosage of $200 \mathrm{mg}$. daily, upon blood pressure, serum sodium and potassium, and urinary volume, sodium and potassium in normotensive rabbit.

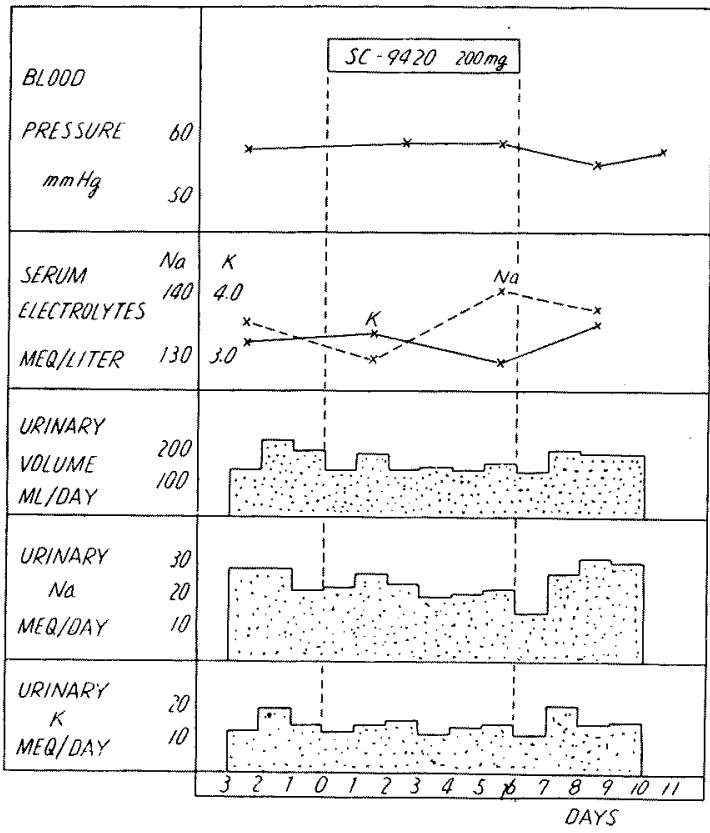


teristic effects only in the presence of aldosterone-like steroid, and presumably the inhibition effect seems to occur in the kidney tubule where mineralocorticoid primarily works. ${ }^{17}$ Thus, as aldosterone is present in a minute amount in normal animals, SC-9420 is relatively ineffective. So it is probable that in renal hypertension the level of aldosterone secretion is increased.

The effect of spironolactone on urinary electrolytes was the same as reported by Liddle. ${ }^{18)}$ There was an increase in urinary sodium, chloride and urinary volume, mostly accompanied by a slight decrease in urinary potassium. The elevation of serum potassium by spironolactone administration was not accompanied with proportionate reduction of urinary potassium. Presuming from this fact, it seems that intracellular potassium moved out to the extracellular space.

Blood pressure fell immediately after spironolactone administration and, thereafter, did not change significantly during the administration, but the increase of urinary sodium occurred later than the reduction of blood pressure. This fact, we feel, offers a strong evidence that the antihypertensive effect of spironolactone was not mediated by its action upon water and electrolyte metabolism. It is assumed that spironolactone itself has an action to decrease blood pressure. These findings indicate that the renal anti-aldosterone effects and the blood pressure effects of SC-9420 are separable and relatively independent actions. The mode of action which spironolactone induces a reduction in blood pressure is not clear. The antihypertensive and the natriuretic effects of spironolactone, after either oral or parenteral administration, were all almost the same.

\section{SUMMARY}

Spironolactone was administered to rabbits with experimental renal hypertension. The blood pressure of these rabbits was decreased during spironolactone therapy. A marked increase in sodium and water excretion was noted on the third day, but potassium excretion did not change at that time. Treatment with spironolactone caused a rise of serum potassium in hypertensive rabbits. It is probable that spironolactone moves intracellular potassium out to extracellular space.

Assuming from these results, water and electrolyte metabolism is not normal in the experimental renal hypertension, probably accompanied with excessive mineralocorticoid secretion. But the abnormal water and electrolyte metabolism, and hyperaldosteronism in experimental renal hypertension seem to play an independent different role in the development and maintenance of arterial hypertension.

We are indebted to Prof. T. Torikai for his continuous leadership throughout this study. 


\section{References}

1) Rinehart, J.F. et al., Arch Path., 1941, 32, 169.

2) Fisher, J.A. \& Hewer, T.F., J. Path. \& Bact., 1947, 59, 605.

3) Hanley, H., G. Brit. J. Urol., 1957, 29, 359.

4) Goldblatt, H., Ann. Int. Med., 1937, 11, 69.

5) Blalock, A. \& Levy, S.E., Ann. Surg., 1937, 106, 826.

6) Collins, D.A. \& Wood, E.H., Am. J. Physiol., 1938, 123, 224.

7) Page, E.W. et al., Am. J. Physiol., 1946, 147, 471.

8) Sturtevant, F.M., J. Pharmacol. \& Exper. Therap., 1957, 121, 369.

9) Sturtevant, F.M. \& Radeliffe, M.J.,J. Pharmacol. \& Exper. Therap., 1958, 122, 73 A.

10) Sturtevant, F.M., Circulation, 1958, 17, 773.

11) Sturtevant, F.M., J. Lab. \& Clin. Med., 1958, 52, 899.

12) Watson, E.M., J Lab. \& Clin. Med., 1926-7, 12, 706.

13) Deane, H.W. \& Masson, G.M.C., J. Clin. Endocrinol., 1951, 11, 193.

14) Wakerlin, G.E., Physiol. Rev., 1955, 35, 555.

15) Laragh, J.H. et al., Circulation, 1959, 20, 725.

16) Hollander, W. \& Chobanian, A.V., Circulation, 1959, 20, 713.

17) Kagawa, C.M. et al., J. Pharmacol. \& Exper. Therap., 1959, 126, 1959.

18) Liddle, G.W., Arch. Int. Med., 1958, 102, 998. 